or about one-eighth English measurement. It is not arranged for cover-glass correction, as this is not necessary, that function being obtained by means of the sliding tube of the body. It contains five lenses, and has a numerical aperture of 1.4, which is a trifle less than has been obtained in England and America (1.5); but, so far as its optical qualities are concerned, it is far superior to any thing ever before made, the new glass permitting the absolute correction of all aberrations. The field is perfectly flat, the minutest object in the extreme edge of the field showing as sharply and clearly as though it were in the centre. With the vertical illuminator, an amphipleura (silvered) is resolved into pearls, - not merely in spots, but over the entire frustule, - and with such clearness that these pearls can be counted. In the study of other diatoms, I have found details which have hitherto escaped notice. As to the bacteria, details of structure are shown that have never before been seen, - details that will without doubt serve to differentiate them by ocular means. Accompanying the objective are three eye-pieces, - two for direct use, and one for photography. They are also made of the new glass and by entirely new formulae."

The HeALTH COMMISSIONER of Chicago has prohibited the removal of milk from the cow-stables of that city which are infected with contagious pleuro-pneumonia. As was to be expected, the owners rebel, and, unless closely watched, will doubtless smuggle the milk into the market. The New York health authorities are inspecting the beef which comes to the city from Chicago in refrigerator-cars. Thus far no unwholesome meat has been detected. This inspection is of value, as some carcasses may be so diseased as to be detected; but unless the inspection is made at the slaughterhouses, where the viscera can also be examined, no guaranty can be given that the meat is that of a healthy animal. The last report indicated that three thousand animals were under quarantine in Chicago.

THE RECENT DEATH of two persons in a New York hotel from the inhalation of illuminatinggas draws attention again to the dangers connected with this service. Just how the accident occurred has not yet been satisfactorily explained ; but it is probable, that, as the victims were city residents, they did not resort to the method of extinguishing the light usually adopted by stran- gers from the country, namely, by blowing it out. It is more than likely that the flame was a small one, which was either blown out by a current of air, or extinguished by a change of pressure within the pipes. In many occupied buildings the old-fashioned gas-cocks, those without stops, still exist; and it not infrequently happens, that, by an incomplete closure of the outlet, gas escapes into the room, sometimes to a dangerous degree. It would be a valuable improvement in the management of our cities and towns, if it was made the duty of some of the municipal departments to periodically inspect the gas pipes and fixtures of all buildings occupied as residences, with power to compel the owners to provide the most perfect apparatus, or, failing so to do, to be liable to a fine, which could be used by the authorities to do the necessary work themselves. In recent years valuable laws have been passed, regulating the construction and drainage of dwellings, and the same supervision could be advantageously exercised over the arrangement and quality of the gas-pipes and faucets.

\section{THE GERMAN ASSOCIATION OF NATU RALISTS AND PHYSICIANS.}

THE meetings of the Association of German naturalists and physicians closed this afternoon, very successful according to German, but hardly so according to American notions. The association is a curiosity in itself : for although it now has held its fifty-ninth meeting, and has been in existence since 1822, it has no permanency whatever, but dissolves at the close of every meeting, after it has appointed a president, a vice-president, and a secretary for the next year, and has selected the next meeting-place, which must be the residence of the first and third officer. Into the hands of these gentlemen is given every thing pertaining to the following gathering, which always commences on Sept. 18. The Association of German naturalists and physicians has no corporate existence, owns no property whatever, and meets for the avowed purpose of facilitating acquaintances among the members. Scientific discussions are of secondary importance. For instance : that which a section apparently considers first is, " Where shall we drink our Frïh-schoppen, and which shall be our Stamm-kneipe?" And in the 'Stamm-kneipe,' behind the beer-glass, discussions are held often more profound than those at the official meetings. The advocates of the often-quoted assertion that beer is always injurious will have to acknowledge themselves de- 
feated, when they see about five thousand professors, doctors, and students, who gathered here during the past week, all hale and hearty, although many of ripe old age, all of whom drink beer in larger or smaller quantities; and as for the statement that he who 'drinks beer thinks beer,' it is a well-known fact that German thought leads the world in more than one branch of science.

Every naturalist and every physician who has published something in scientific or in medical journals is eligible to membership on the payment of a certain fee: here in Berlin it was placed at fifteen marks. Those who are interested in science, but have not published any thing, can, on payment of the same sum, become associates, but not members ; i.e., they are entitled to attend all meetings and entertainments, but are not allowed to vote. No election of members is held : only a simple announcement of the facts, and payment of the fees, are needed to obtain a membership card ; and so great and so just is the confidence which these gentlemen place in the applicants' honesty, that cases where membership certificates have been obtained under false pretences are so very few during all these years, that they can be ignored entirely.

The sections, to the number of thirty, have no permanent officers. At every meeting a chairman and a secretary are elected, although the latter generally remains in office during the whole week, because it is his duty to make the necessary report, and collect the abstracts of the papers read before the section, for the 'Tageblatt' of the next day. This Tageblatt is a very commendable institution, and takes the place of the 'Daily programmes' of the American association in a very decidedly improved form. It is issued every morning, at about nine o'clock, and contains the membership list, announcements, programme of the day, and abstracts of all the papers read before all the sections on the preceding day. This year's Tageblatt forms a small quarto volume of four hundred pages.

The registry shows 2,214 members, 1,914 associates, and 1,475 ladies, who are classed by themselves. The position of the ladies in the Association of German naturalists and physicians can, in part at least, be defined by the reproduction of a short abstract from one of the numbers of the Tageblatt : -

" His majesty the emperor has been pleased to order a special performance at the Royal opera, as well as at the Royal theatre, exclusively for the entertainment of the Association of German naturalists and physicians. . . LADIES ARE NOT ADMITTED !"

In view of the large numbers present, there was nothing wrong in this decree, according to German notions at least; but in view of the fact that at least one-third of the members were natives of Berlin, who could have visited either of the theatres at any other time, it would have been more just if these gentlemen had been excluded. But they were all there as 'invited guests of the emperor' (nothing small, indeed); and many of those who had perhaps travelled from the farthest point of Germany had to take a back seat, and, in addition, leave their wives at the hotels or stay away altogether.

The large number of social entertainments furnished by the local committee as well as by the city government were as complete and elaborate as possible. Excursions, exhibitions, regattas, suppers, balls, etc., gave an abundant opportunity to comply with $\S 2$ of the very short constitution : "The aim of the association is to offer an opportunity to the naturalists and physicians of Germany to form a personal acquaintance."

Pohlman.

\section{THE MOUNTING OF MUNGO.}

THE common practice in mounting large mammals is to first make the legs, and, having fastened them securely to a backbone of plank, to pack the remainder of the body with loose filling. While this does well enough for long-haired animals, whose muscles are concealed, for those that are scantily clad some other methods must be adopted in order to reproduce correctly form and features.

To build up an animal that will be lank and flabby is the height of taxidermic art, and a brief description of the manner in which the elephant Mungo was mounted at the national museum will show the methods by which such results may be obtained.

Mungo was an African elephant about six years old, belonging to Forepaugh's menagerie, that thoughtfully selected Washington as the place of his demise. Mr. William T. Hornaday, the distinguished taxidermist, saw in this event an opportunity of putting the new principles of mounting into practice.

The first step in the process of mounting was to take a series of careful measurements of the body, showing its length, height, and girth at various points, and the dimensions of the limbs and the trunk. These were supplemented by sundry drawings, and by plaster casts of the head and of the limbs of one side. The more care was necessary in this, owing to the fact that the entire skeleton was to be mounted separately, and thus no guide left to the position of the joints. This done, the skin was removed, and transferred to a bath 